\title{
A rare case of a parathyroid adenoma inside a parathyroid cyst
}

\author{
Um caso raro de adenoma de paratireoide em um cisto de paratireoide
}

Spyridon N. Karras ${ }^{1,2}$, loannis Koutelidakis ${ }^{3}$, Panagiotis Anagnostis ${ }^{2}$, Gesthimani Mintziori ${ }^{1}, 2$, Nikolaos Pontikides' ${ }^{1}$, Dimitrios G. Goulis ${ }^{2}$

1 Department of Endocrinology, Diabetes and Metabolism, Agios Pavlos General Hospital, Thessaloniki, Greece 2 Unit of Reproductive Endocrinology, First Department of Obstetrics and Gynecology, Medical School, Aristotle University of

Thessaloniki, Thessaloniki, Greece ${ }^{3}$ Department of Surgery, General Hospital G. Gennimatas, Thessaloniki, Greece

Correspondence to: Spyridon N. Karras Venizelou 34b, Pilea, PO Box 55535 - Thessaloniki, Greece karraspiros@yahoo.gr

Received on Jan/19/2014 Accepted on Mar/29/2014

\section{SUMMARY}

Parathyroid cysts (PCs) are rare lesions, located in the neck and anterior mediastinal region. The vast majority are non-functioning, presented as nodular cervical lesions. Large, non-functioning PCs can manifest with compressive symptoms of the surrounding tissues. Rarely, PCs produce excessive amounts of parathyroid hormone (PTH), resulting in primary hyperparathyroidism. We report a case of functional PC, describing its diagnostic and therapeutic approach. Arq Bras Endocrinol Metab. 2014;58(7):776-8

\section{SUMÁRIO}

Os cistos de paratireoide (PCs) são lesões raras, localizadas no pescoço e na região do mediastino anterior. A grande maioria é não funcionante, apresentando-se como lesões cervicais nodulares. PCs não funcionantes de grandes dimensões podem se manifestar com sintomas compressivos. Raramente, PCs produzem quantidades excessivas de hormônio da paratireoide (PTH), o que resulta em hiperparatiroidismo primário. Relatamos um caso de PC funcional, descrevendo sua abordagem diagnóstica e terapêutica. Arq Bras Endocrinol Metab. 2014;58(7):776-8

DOI: 10.1590/0004-2730000003211

\section{INTRODUCTION}

$\mathrm{P}$ arathyroid cysts (PCs) were first described in 1880 and they comprise rare lesions of the neck or mediastinum, with more than eight five percent of them located in the neck, usually involving the lower parathyroid glands, and the rest of them located between the mandible and mediastinum (1-4). PCs are subdivided into functioning and nonfunctioning depending on their ability to secrete PTH or not. The vast majority are non-functioning and are presented as nodular cervical lesions (1). Large, non-functioning PCs can manifest with compressive symptoms of the surrounding tissues (2). The aim of this paper is to report and discuss a case of parathyroid adenoma within a $4 \mathrm{~cm}$ PC.

\section{CASE REPORT}

A 59-year-old woman was referred to a physician for evaluation and treatment of newly diagnosed diabetes mellitus type 2 . She reported severe constipation, polydipsia, fatigue, weakness and proximal muscle weakness of two-year duration. As her symptoms were attributed to uncontrolled diabetes, she was started on basal insulin. Although glycemic control was achieved, her symptoms deteriorated. For that reason, she was referred to our department.

Previous medical history included hypertension and hyperlipidemia. Eight years ago, she was diagnosed as having hyperthyroidism and received methimazole, at a dose of $10 \mathrm{mg}$ daily, for two years. She remained euthyroid since then, with no anti-thyroid treatment. The patient had a palpable nodule at the anatomical region of the right thyroid lobe. The laboratory evaluation in our department showed elevated concentrations of calcium $(\mathrm{Ca})(11.9 \mathrm{mg} / \mathrm{dL}$, reference range 8.4-10.4) and PTH $(300 \mathrm{pg} / \mathrm{mL}$, reference range $10-65)$, whereas thyroid function tests, serum phosphorus, creatinine and albumin were within the reference range and D-XA 
densitometry demonstrated no osteopenia or osteoporosis. Thyroid ultrasound (US) revealed hypoechogenic nodules bilaterally and a cystic structure (dimensions $2.6 \times 1.8 \times 3.0 \mathrm{~cm}$ ) below the right thyroid lobe. A ${ }^{99 \mathrm{~m}} \mathrm{Tc}$-Sestamibi scan revealed hyper-functioning tissue in the lower part of the right thyroid lobe.

The patient was referred for parathyroidectomy. At the anatomical place of the right superior parathyroid gland, a large, mixed (i.e. solid and cystic components) structure was found and extracted without any capsule rupture (Figure $1 \mathrm{~A}$ and $\mathrm{IB}$ ). Serum PTH concentra-
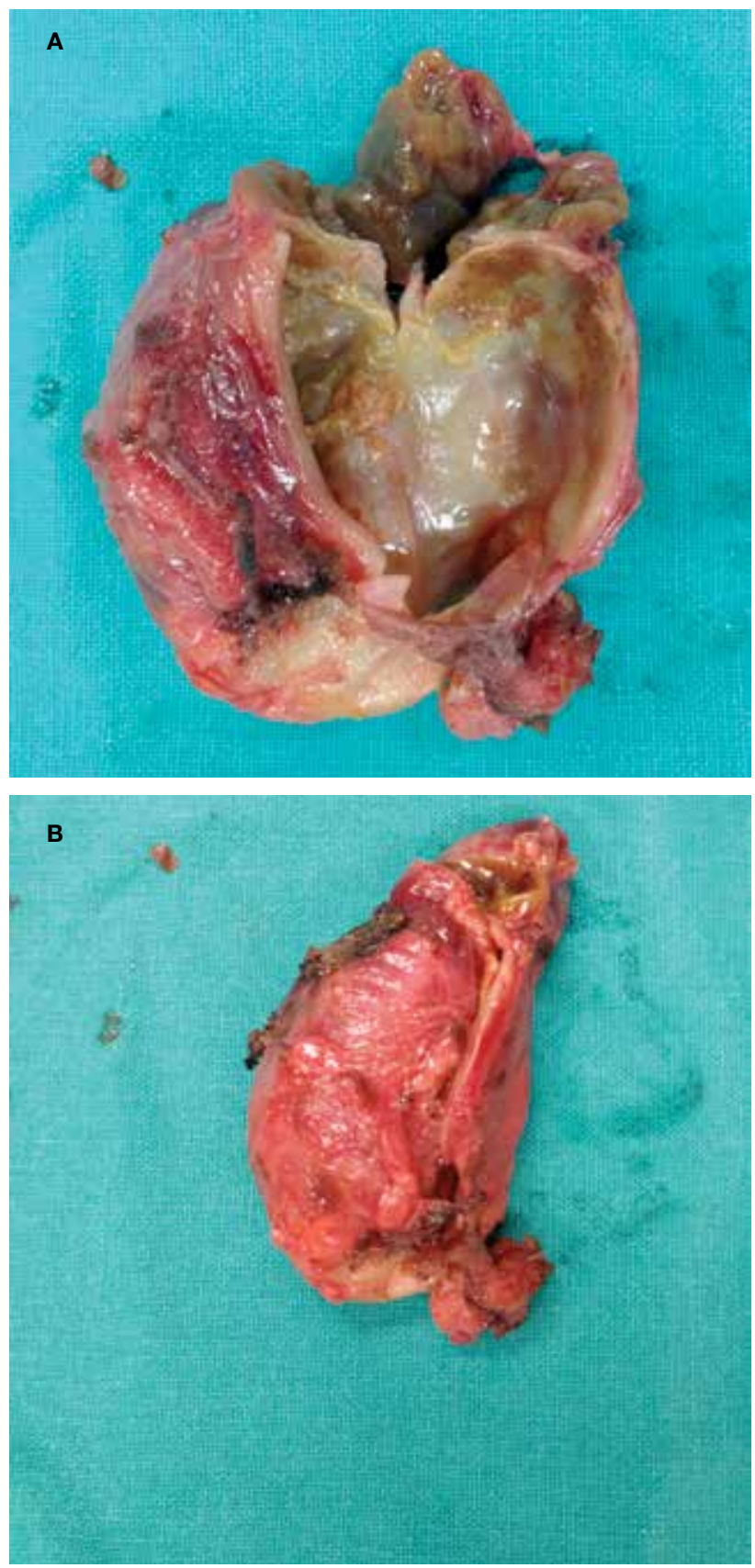

Figure 1. Surgical specimen revealing cystic (A) and solid (B) components. tions, that were measured by means of Electrochemiluminescence assay (ECL), were decreased $100 \%$ and fell within reference range $20 \mathrm{~min}$ after removal of the structure. The ipsilateral parathyroid gland was explored and found to be macroscopically normal. Total thyroidectomy was performed as well. The patient was discharged $24 \mathrm{~h}$ later, free of post-operative complications, and put on oral calcium and vitamin D supplementation that was suspended 4 weeks post-operatively, with no symptoms or signs of hypocalcaemia or tetany. Histology reported a parathyroid adenoma within a 4 $\mathrm{cm}$ PC. The wall of the PC was fibrous, with deposits of Ca salts, cholesterol crystals, hemosiderin-stained macrophages and islets of parathyroid tissue, consisting of principal, acidophiles and few clear cells. There were no areas within the cyst showing acute and chronic organization consistent with cystic degeneration of a parathyroid adenoma. Small, colloid nodules were detected in the thyroid gland, with no signs of malignancy. One year after the initial diagnosis, the patient remains euthyroid, being on levothyroxine supplementation; Ca and $\mathrm{PTH}$ concentrations are within the reference range.

\section{DISCUSSION}

Non-functioning PCs represent $80 \%$ of all cases, manifest no hormonal hypersecretion, appear in $40-50 \%$ of cadaveric autopsies and are located in the inferior parathyroid glands (3). This is a case of parathyroid adenoma within a $4 \mathrm{~cm}$ PC. Functional PCs represent 20\% of cases, manifest PTH hypersecretion, are revealed in $0.3-3 \%$ of the parathyroid glands removed due to primary hyperparathyroidism (3), have no typical location and are found predominantly in men $(3,4)$.

PCs can be divided in five categories, based upon the presumed mechanism of cyst formation: i) developmental, arising from vestigial remnants of the third and fourth branchial clefts; ii) coalescence of microcysts into macrocysts; iii) degeneration of an adenoma, or rarely carcinoma, into a pseudocyst; iv) accumulation of fluid in the parathyroid gland, forming a retention cyst; and $v$ ) arising from vestigial remnants of Kursteiner canals $(5,6)$.

The heterogeneous clinical presentation of PCs is determined by their hormonal activity, size and location (7). Small, non-functioning PCs can be asymptomatic, discovered incidentally during physical or imaging evaluation for other reasons, or after surgical excision of thyroid nodules $(8,9)$. Large, non-functioning PCs 
may produce local symptoms. Functioning PCs are manifested with signs and symptoms of hyperparathyroidism, including hypercalcaemic crisis $(10,11)$.

Diagnostic workup includes physical examination, biochemical evaluation, neck imaging [US, ${ }^{99 \mathrm{~m} T c-S e s-}$ tamibi scan, computed tomography (CT), magnetic resonance imaging (MRI)] and fine needle aspiration biopsy (FNAB). Neck US is a useful tool in differentiating a PC from thyroid or other cystic masses (12). Radio-nucleotide scan usually reveals areas with decreased or no uptake, mimicking cold nodules. ${ }^{99 \mathrm{~m} T \mathrm{Tc}-S e s t a m i b i}$ or ${ }^{201} \mathrm{Th}-{ }^{99} \mathrm{Tc}$ scans provide equivocal results, even in cases of functioning PC (13). CT or MRI can be useful in cases with substernal extension or when symptoms of compression occur, by defining the cystic nature of the mass, without accurately differentiating PC from other cystic masses in this region (14). Typical FNAB finding is a watery, colourless, crystal-clear fluid; the diagnosis can be established by elevated concentrations of PTH in the aspirated fluid. An algorithm for the diagnostic work-up of patients with suspected PCs has been proposed by our group (4).

Histologically, non-functional PCs are lined by a flattened cuboidal or columnar epithelium; several types of parathyroid cells are found in their wall. On the contrary, functional PCs lack a formed lining and are accordingly termed as pseudo-cysts. They may contain hemorrhagic or necrotic foci and brown or turbid fluid with hemosiderin-stained macrophages (15). In a few cases, an adenoma is found within the cyst.

Complete remission of non-functioning PCs can be achieved by FNAB. In case of recurrence (16), sclerotherapy with tetracycline and alcohol can be effective, but may result in fibrosis and recurrent laryngeal nerve palsy (17). Simple observation can be suggested for small, asymptomatic PCs. The treatment of choice in cases of symptomatic or functional PCs, as in our case, is surgical resection. The approach is cervical, preferably by minimally invasive surgery (18); thoracotomy or median sternotomy may be required for some mediastinal PCs (18). Intra-operative measurements of PTH are valuable in the evaluation of a complete resection, but they can be misleading when rupture has occurred during surgery. Patients with functional, large PC are more likely to develop post-operative symptomatic hypocalcemia (3).
In conclusion, PCs comprise a challenging clinical entity, requiring a high index of clinical suspicion. The understanding of its diagnostic and therapeutic approach constitutes a valuable knowledge for all health professionals dealing with neck lesions.

Disclosure: no potential conflict of interest relevant to this article was reported.

\section{REFERENCES}

1. Alvi A, Myssiorek D, Wasserman P. Parathyroid cysts: current diagnostic and management principles. Head Neck. 1996;18:370-3.

2. Braccini F, Epron JP, Roux C, Gabert K, Richard-VittonT, Korchia D, et al. Essential parathyroid cysts: a misleading lesion. Rev Laryngol Otol Rhinol (Bord). 2000;121:165-8.

3. Fortson JK, Patel VG, Henderson VJ. Parathyroid cysts: a case report and review of the literature. Laryngoscope. 2001;111:1726-8.

4. Pontikides N, Karras S, Kaprara A, Cheva A, Doumas A, Botsios $D$, et al. Diagnostic and therapeutic review of cystic parathyroid lesions. Hormones (Athens). 2012;11:410-8.

5. Ferrara BE, Hazell S, ParkerTH, Rutland ED. Parathyroid cyst. South Med J. 1985;78:528-32.

6. Page GV, Burke ML, Metzger WT. Parathyroid cysts. Am Surg. 1984;50:29.

7. Ihm PS1, Dray T, Sofferman RA, Nathan M, Hardin NJ. Parathyroid cysts: diagnosis and management. Laryngoscope. 2001;111:1576-8.

8. Ujiki MB, Nayar R, Sturgeon C, Angelos P. Parathyroid cyst: often mistaken for a thyroid cyst. World J Surg. 2007;31:60-4.

9. Calandra DB, Shah KH, Prinz RA, Sullivan H, Hofmann C, Oslapas $\mathrm{R}$, et al. Parathyroid cysts: a report of eleven cases including two associated with hyperparathyroid crisis. Surgery. 1983;94:887-92.

10. McCoy KL, Yim JH, Zuckerbraun BS, Ogilvie JB, Peel RL, Carty SE. Cystic parathyroid lesions: functional and nonfunctional parathyroid cysts. Arch Surg. 2009;144:52-6.

11. Gurbuz AT, Peetz ME. Giant mediastinal parathyroid cyst: an unusual cause of hypercalcemic crisis - Case report and review of the literature. Surgery. 1996;120:795-800.

12. Cappelli C, Rotondi M, Pirola I, De Martino E, Leporati P, Magri F, et al. Prevalence of parathyroid cysts by neck ultrasound scan in unselected patients. J Endocrinol Invest. 2009;32:357-9.

13. Gough IR. Parathyroid cysts. Aust N Z J Surg. 1999;69:404-6.

14. Kato H, Kanematsu M, Kiryu T, Iwata H, Shirahashi K, Matsumoto $\mathrm{S}$, et al. Nonfunctional mediastinal parathyroid cyst: imaging findings in two cases. Clin Imaging. 2008;32:310-3.

15. Lerud KS, Tabbara SO, DelVecchio DM, Frost AR. Cytomorphology of cystic parathyroid lesions: report of four cases evaluated preoperatively by fine-needle aspiration. Diagn Cytopathol. 1996;15:306-11.

16. Prinz RA, Peters JR, Kane JM, Wood J. Needle aspiration of nonfunctioning parathyroid cysts. Am Surg. 1990;56:420-2.

17. Sanchez A, Carretto $H$. Treatment of a nonfunctioning parathyroid cyst with tetracycline injection. Head Neck. 1993;15:263-5.

18. Spitz AF. Management of a functioning mediastinal parathyroid cyst. J Clin Endocrinol Metab. 1995;80:2866-8. 